\title{
Muscle type-specific responses of myoD and calpain 3 expression to recombinant porcine growth hormone in the pig
}

\author{
X. Yang, J. Chen, Q. Xu and R. Zhao ${ }^{\dagger}$ \\ Key Laboratory of Animal Physiology and Biochemistry, Nanjing Agricultural University, Nanjing 210095, People's Republic of China
}

(Received 29 August 2006; Accepted 28 March 2007)

\begin{abstract}
Sixteen castrated male Large White $\times$ Landrace pigs were employed to investigate the muscle type-specific changes of gene expression in response to recombinant porcine growth hormone (rpGH) administration. Pigs were injected intramuscularly with $r p G H(4 \mathrm{mg} /$ day, $\mathrm{n}=8)$ or saline $(\mathrm{n}=8)$ for 28 days. Semi-quantitative reverse transcription-polymerase chain reaction $(R T-P C R)$ was used to determine the mRNA abundance of genes related to muscle growth in longissimus dorsi (LD) and semitendinosus (ST) muscles. Myofibre-type composition was characterised by the ratio of the expression of myosin heavy chain (MyHC) 1, 2a or $2 b$ relative to $2 x$. The results showed that the relative myofibre-type composition of neither $L D$ nor ST was affected by rpGH administration. $r p G H$ administration did not induce significant changes in the abundances of myostatin and myogenin mRNA in both types of muscle. MyoD and calpain 3 mRNA were significantly increased after rpGH treatment in ST muscle, whereas the difference was not significant in $L D$ muscle. A tendency of down-regulation was observed for PGC-1 $\alpha$ mRNA expression in ST muscle of rpGH-treated group $(\mathrm{P}=0.16)$. These results suggest that myoD, calpain 3 and probably $P G C-1 \alpha$ may be involved in the mechanism of exogenous GH action on skeletal muscle growth; rpGH up-regulates mRNA expression of myoD and calpain 3 in a muscle type-specific manner, being more remarkable in $S T$ than in $L D$, whereas no influences of rpGH on the mRNA expression of myostatin and myogenin were detected.
\end{abstract}

Keywords: calpain 3, MyHC, MyoD, pigs, rpGH

\section{Introduction}

The effect of exogenous growth hormone (GH) on animal growth and meat quality has been studied extensively during the last decades. It has been confirmed that exogenous GH can improve animal daily weight gain, feed efficiency and lean accretion rate (Campbell et al., 1989; Brameld et al., 1996). The responses of hormones and genes in somatotropic axis, such as GH receptor, IGF-1 and IGF-1 receptor have also been observed closely as the major components in the pathway of $\mathrm{GH}$ action (Louveau and Bonneau, 1996; Klindt et al., 1998; Zhao et al., 2003). However, the responses of genes participating in myogenesis and myofibre-type transformation in skeletal muscle have received less attention, despite the fact that skeletal muscle is one of the major targets for $\mathrm{GH}$ action and economically the most important part in meat animals.

The skeletal muscle myofibres in postnatal pigs can be classified into four major types, I, Ila, IIx and IIb, according to their metabolic and contractive characteristics. Type I

${ }^{\dagger}$ E-mail: zhao.ruqian@gmail.com fibres (red; slow-twitch) are the smallest, oxidative fibres with high lipid content and many mitochondria, whereas type llb fibres (white; fast-twitch) are the largest, glycolytic fibres possessing high glycogen content and few mitochondria. Type Ila and IIx fibres are intermediate oxidative-glycolytic fibres. Generally, lla fibres are more closely related to type I fibres and IIx fibres are more similar to Illb fibres (Hamalainen and Pette, 1993). The longissimus dorsi (LD) and semitendinosus (ST) muscles differ in myofibretype composition. LD muscle is composed primarily of glycolytic myofibres, whereas ST muscle has different myofibre-type composition depending on anatomical location. The deep medial portion comprises largely of oxidative myofibres. The myofibre-type composition contributes greatly to both skeletal muscle growth and meat quality (Klont et al., 1998; Eggert et al., 2002; Chang et al., 2003). Compared with its well-defined positive effect on myofibre hypertrophy, the influence of rpGH on myofibre-type composition is still under debate. Many studies reported that exogenous GH had no effect on the skeletal muscle fibre composition (Solomon et al., 1988 and 1990; Beermann et al., 1990; Czerwinski and Martin, 1994), while some experiments 
demonstrated divergent results (Solomon et al., 1991 and 1994).

Skeletal muscle growth involves both myofibre-type transformation and myofibre hypertrophy in pigs. Recently, some genes are reported to be involved in these two processes, such as myoD and myogenin (Olson, 1990; Li and Olson, 1992; Molkentin and Olson, 1996) and myostatin (Lee and McPherron, 1999; Sharma et al., 2001; Yang and Zhao, 2006). Meanwhile, calpain 3, a member of calciumdependent protease family, acts as a skeletal musclespecific regulatory protein (Sorimachi et al., 1989 and 1990) and participates in the regulation of myofibre hypertrophy. Peroxisome proliferator-activated receptor $\gamma$ coactivator- $1 \alpha$ (PGC-1 $\alpha$ ), a transcriptional coactivator expressed in several tissues including skeletal muscle, was found to activate mitochondrial biogenesis and oxidative metabolism (Knutti and Kralli, 2001) and was reported to drive the formation of slow-twitch muscle fibres in rodents (Lin et al., 2002). However, data describing the responses of these genes to exogenous GH in pigs are scarce (Ji et al., 1998a and 1998b).

Therefore, the objectives of the present study were (1) to provide an evidence of the myofibre-type composition responding to rpGH both in LD and ST muscles and (2) to clarify the responses of genes related to skeletal muscle growth at the level of transcription in LD and ST muscles upon exogenous $\mathrm{GH}$ administration.

\section{Material and methods}

\section{Animals and experimental design}

The experiment was undertaken following the guidelines of the regional Animal Ethics Committee. Sixteen castrated male Large White $\times$ Landrace pigs with average initial body weight of $50.8 \mathrm{~kg}$ (from 48 to $55 \mathrm{~kg}$ ) were housed individually in floor pens and fed according to the breed standards of USA (National Research Council, 1998). Pigs were randomly allotted to treatment or control group. The treatment group was injected intramuscularly with recombinant porcine growth hormone ( $\mathrm{rpGH}, 4 \mathrm{mg} /$ day) in the extensor area of the neck and the control group with vehicle at $0900 \mathrm{~h}$ for 28 days. Animals were slaughtered $4 \mathrm{~h}$ after the final injection. LD muscle adjacent to the last rib and the deep medial portion of ST muscle were taken immediately (within 5 to 10 min of death) and rapidly frozen in liquid nitrogen, and then stored at $-80^{\circ} \mathrm{C}$. rpGH was obtained from Shenzhen Lupeng Agricultural Hi-tech $\mathrm{Co}$. Ltd, People's Republic of China.

\section{RNA extraction and reverse transcription (RT)}

Total RNA was extracted from the tissue samples with a single-step method of RNA extraction by acid guanidinium thiocyanate-phenol-chloroform (Chomczynski and Sacchi, 1987). Total RNA concentration was then quantified by measuring the absorbance at $260 \mathrm{~nm}$ in a photometer (Eppendorf Biophotometer). Ratios of absorption (260/280 nm) of all preparations were between 1.8 and 2.0. Aliquots of RNA samples were subjected to electrophoresis through a $1.4 \%$ agarose-formaldehyde gel to verify their integrity.

Two micrograms of total RNA was reverse transcribed by incubation at $42^{\circ} \mathrm{C}$ for $1 \mathrm{~h}$ in a $25 \mu \mathrm{l}$ mixture consisting of $10 \mathrm{U}$ avian myeloblastosis virus reverse transcriptase, $10 \mathrm{U}$ RNase inhibitor, $12 \mu \mathrm{mol} / /$ random primers, $50 \mathrm{mmol} / \mathrm{l}$ Tris- $\mathrm{HCl}\left(\mathrm{pH}\right.$ 8.3), $10 \mathrm{mmol} / \mathrm{l} \mathrm{MgCl}_{2}, 50 \mathrm{mmol} / / \mathrm{KCl}$, $10 \mathrm{mmol} / \mathrm{I} \mathrm{DDT}, 0.5 \mathrm{mmol} / \mathrm{l}$ spermidine and $0.8 \mathrm{mmol} / /$ each dNTP. The reaction was terminated by heating at $95^{\circ} \mathrm{C}$ for $5 \mathrm{~min}$ and quickly cooling on ice.

\section{The expression of myosin heavy chain (MyHC) isoforms} A multiplex PCR procedure reported by Tanabe et al. (1999) was followed to determine the relative expressions of $\mathrm{MyHC}$ isoforms in the muscle of pigs, employing four sense primers specific for MyHC (MyHC I: 5'-AGCCTCTTTCTTCTC CCAGGGACATTC-3'; MyHC 2a: 5'-CACTTGCTAAGAGGGAC CTCTGAGTTCA-3'; MyHC 2b: 5'-CATCTGGTAACATAAGAGG TACATCTAG-3'; MyHC 2x: 5'-CTTTCCTCATAAAGCTTCAAG TTCTGCC- $3^{\prime}$ ) and a common anti-sense primer (5'-ATCC AGGCTGCGTAACGCTCTTTGAGGTTGTA-3') used in that publication. MyHC $1,2 \mathrm{a}$ and $2 \mathrm{~b}$ were respectively amplified together with MyHC $2 x$ in the same PCR reaction.

\section{The expression of myosatin, myogenin, myoD, calpain 3 and PGC-1 $\alpha$ mRNA}

Two microlitres of RT reaction mix was used for PCR in a final volume of $25 \mu$ l containing $0.5 \mathrm{U}$ Taq DNA polymerase, $5 \mathrm{mmol} / \mathrm{l}$ Tris- $\mathrm{HCl}(\mathrm{pH} 9.0), 10 \mathrm{mmol} / \mathrm{l} \mathrm{NaCl}, 0.1 \mathrm{mmol} / \mathrm{l} \mathrm{DDT}$, $0.01 \mathrm{mmol} / / \mathrm{EDTA}, 5 \%$ (w/v) glycerol, $0.1 \%(\mathrm{w} / \mathrm{v})$ Triton $\mathrm{X}-100,0.2 \mathrm{mmol} / \mathrm{l}$ each dNTP, 1.0 to $2.0 \mathrm{mmol} / / \mathrm{MgCl}_{2}$ and $0.5 \mu \mathrm{mol} / / \mathrm{l}$ of each primer specific for each gene. The PCR primers were designed using Primer Premier 5.0 and were synthesised by Haojia Biotech. Ltd., China. The nucleotide sequences of these primers and the PCR conditions are shown in Table 1. The Quantum RNA 185 Internal Standards kit (Catalogue no. 1716, Ambion Inc., Austin, TX, USA) containing primers and competitors was used to normalise variations in pipetting and amplification.

Different controls were set to monitor the possible contaminations of genomic DNA and environment DNA both at the stage of RT and RCR. The pooled samples made by mixing equal quantity of total RNA from all samples were used for optimising the PCR condition and normalising the intra-assay variations. All samples were included in the same run of RT-PCR and repeated at least for three times.

Quantitation of PCR products and statistical analysis An aliquot of PCR products was analysed by electrophoresis on $2 \%$ agarose (for muscle growth-related genes) or $8.0 \%$ PAGE (for MyHC isoforms) gels. The gels were stained with ethidium bromide and photographed with digital camera. The net intensities of individual bands were measured using 
Muscle expression of myoD and calpain 3 responding to rpGH

Table 1 Primer sequences of target genes and the condition of PCR

\begin{tabular}{|c|c|c|c|c|}
\hline Target gene & cDNA sequence & PCR product & Primer sequence & PCR condition \\
\hline Myostatin & GenBank AF019623 & 293 bp (56-348) & $\begin{array}{l}\text { F: } 5^{\prime} \text {-gtcccgtggatctgaatg-3' } \\
\text { R: } 5^{\prime} \text {-ttccgtcgtagcgtgata-3' }\end{array}$ & $\begin{array}{l}1.6 \mathrm{~mol} / \mathrm{l} \mathrm{MgCl}_{2}, 94^{\circ} \mathrm{C} 30 \mathrm{~s} \\
52^{\circ} \mathrm{C} 30 \mathrm{~s}, 72^{\circ} \mathrm{C} 40 \mathrm{~s}, 30 \text { cycles }\end{array}$ \\
\hline Myogenin & GenBank U14331 & 230 bp (99-328) & $\begin{array}{l}\text { F: 5'-aggctacgagcggactga-3' } \\
\text { R: 5'-gcagggtgctcctcttca-3' }\end{array}$ & $\begin{array}{l}1.6 \mathrm{~mol} / \mathrm{l} \mathrm{MgCl}_{2}, 94^{\circ} \mathrm{C} 30 \mathrm{~s}, \\
55^{\circ} \mathrm{C} 30 \mathrm{~s}, 72^{\circ} \mathrm{C} 40 \mathrm{~s}, 30 \text { cycles }\end{array}$ \\
\hline MyoD & GenBank U12574 & 383 bp (410-792) & $\begin{array}{l}\text { F: 5'-caacagcggacgacttctatg-3' } \\
\text { R: } 5^{\prime} \text {-gcgcaggatttccacctt-3' }\end{array}$ & $\begin{array}{l}1.6 \mathrm{~mol} / \mathrm{l} \mathrm{MgCl}_{2}, 94^{\circ} \mathrm{C} 30 \mathrm{~s}, \\
62^{\circ} \mathrm{C} 30 \mathrm{~s}, 72^{\circ} \mathrm{C} 50 \mathrm{~s}, 32 \text { cycles }\end{array}$ \\
\hline Calpain 3 & GenBank U05678 & 393 bp (42-434) & $\begin{array}{l}\text { F: 5'-atgccgactgtcattagcg-3' } \\
\text { R: } 5^{\prime} \text {-cagaaaccagcagtcccct-3' }\end{array}$ & $\begin{array}{l}1.6 \mathrm{~mol} / \mathrm{l} \mathrm{MgCl}_{2}, 94^{\circ} \mathrm{C} 30 \mathrm{~s} \\
56^{\circ} \mathrm{C} 30 \mathrm{~s}, 72^{\circ} \mathrm{C} 40 \mathrm{~s}, 26 \text { cycles }\end{array}$ \\
\hline PGC-1 $1 \alpha$ & GenBank AB106108 & 340 bp (1669-2008) & $\begin{array}{l}\text { F: } 5^{\prime} \text {-gagattccgtatcaccacc--3' } \\
\text { R: } 5^{\prime} \text {-ctttcagactcccgcttc-3' }\end{array}$ & $\begin{array}{l}1.6 \mathrm{~mol} / \mathrm{l} \mathrm{MgCl}, 94^{\circ} \mathrm{C} 30 \mathrm{~s}, \\
52^{\circ} \mathrm{C} 30 \mathrm{~s}, 72^{\circ} \mathrm{C} 40 \mathrm{~s}, 31 \text { cycles }\end{array}$ \\
\hline
\end{tabular}

Table 2 Ratios of MyHC isoforms expression in LD and ST muscle (values are presented as means \pm s.e.)

\begin{tabular}{|c|c|c|c|c|c|c|c|}
\hline & \multicolumn{2}{|c|}{ LD } & \multicolumn{2}{|c|}{ ST } & \multicolumn{3}{|c|}{ Significance } \\
\hline & Control & Treatment & Control & Treatment & Treatment & Muscle & Treatment $\times$ muscle \\
\hline MyHC $1 / 2 x$ & $0.13 \pm 0.03$ & $0.13 \pm 0.04$ & $0.25 \pm 0.04$ & $0.24 \pm 0.05$ & 0.86 & 0.03 & 0.86 \\
\hline MyHC $2 a / 2 x$ & $0.70 \pm 0.05$ & $0.80 \pm 0.06$ & $0.61 \pm 0.12$ & $0.65 \pm 0.11$ & 0.43 & 0.20 & 0.78 \\
\hline MyHC $2 b / 2 x$ & $0.92 \pm 0.07$ & $0.77 \pm 0.09$ & $0.42 \pm 0.11$ & $0.48 \pm 0.13$ & 0.37 & 0.001 & 0.15 \\
\hline
\end{tabular}

$\mathrm{MyHC}=$ myosin heavy chain; $\mathrm{LD}=$ longissimus dorsi; $\mathrm{ST}=$ semitendinosus; s.e. $=$ standard error.

Kodak Digital Science 1D software (Eastman Kodak Company Rochester, NY, USA). Expression of each isoforms of MyHCs was estimated as the relative value of MyHC 1 , $2 a$ or $2 b$ to MyHC 2x (Table 2). The mRNA expression of other muscle growth-related genes was normalised to $18 \mathrm{~S}$ rRNA.

The results were expressed as mean \pm s.e. Data were analysed using the general linear model procedure (Statistical Packages for the Social Sciences, 2001) and the model included the rpGH treatment, muscle and rpGH treatment $\times$ muscle interaction. Differences were considered significant when $P<0.05$.

\section{Results}

Body weight gain and myofibre composition of $L D$ and ST muscles

The initial and final body weights of pigs were $50.5 \pm 1.3 \mathrm{~kg}$ and $71.5 \pm 1.8 \mathrm{~kg}$ in the $\mathrm{rpGH}$ treatment group and $51.2 \pm 1.6 \mathrm{~kg}$ and $67.8 \pm 1.8 \mathrm{~kg}$ in the control group, respectively. Administration of $\mathrm{rpGH}$ significantly increased the average daily weight gain by $26.1 \%$ $(749.6 \pm 31.5 \mathrm{~g}$ v. $594.6 \pm 17.3 \mathrm{~g}, P<0.05)$.

Relative to MyHC 2x, MyHC $2 b$ was expressed more abundantly in LD muscle than in ST muscle, whereas the opposite was true for MyHC 1. In general, rpGH adminis- tration had no effect on myofibre-type composition in either LD or ST muscle (Table 2).

mRNA expression of growth-related genes in $L D$ and $S T$ muscle

The abundances of $18 \mathrm{~S}$ rRNA showed no difference between LD and ST muscles, and were not altered by rpGH treatment (data not shown). No significant rpGH treatment $\times$ muscle interaction was found for any of the indices evaluated.

Among all the growth-related genes examined in the present experiment, only calpain 3 exhibited significant muscle effect. LD muscle showed significantly higher abundance of calpain 3 mRNA than in with ST muscle in general $(P<0.001)$, as shown in Figure 5 .

No significant treatment effect was seen in the abundances of myostatin and myogenin mRNA irrespective of muscle types (Figures 2 and 3).

Both MyoD and calpain 3 displayed significant treatment effect irrespective of muscle types. However, the up-regulation of MyoD and calpain 3 mRNA expression responding to rpGH reached the level of statistical significance $(P<0.05)$ in ST but not in LD muscle when the treatment effects were analysed in each type of muscle, respectively (Figures 4 and 5). In addition, a tendency of down-regulation for the mRNA expression of PGC- $1 \alpha$ was seen in ST muscle of rpGH-treated group ( $P=0.16$, Figure 6$)$. 
Yang, Chen, Xu and Zhao

(a)

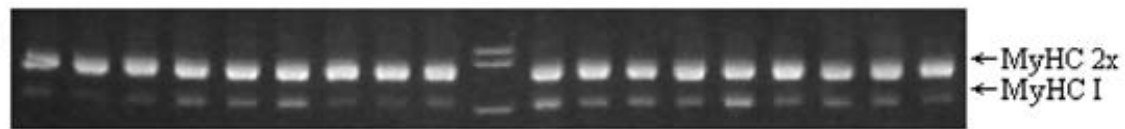

(b)

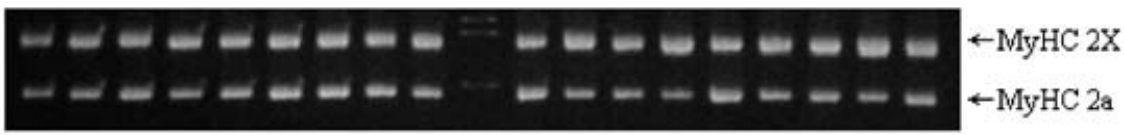

(c)

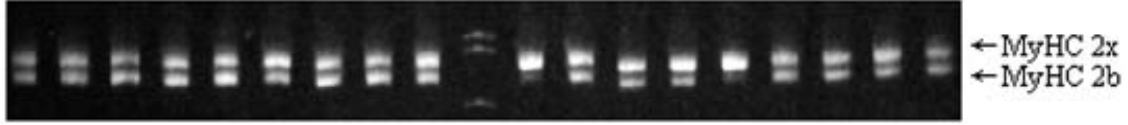

Figure 1 The representative electrophoresis photos of myosin heavy chain (MyHC) types: (a) MyHC 1/2x; (b) MyHC 2a/2x; and (c) MyHC 2b/2x; lane 1-4: control group in longissimus dorsi (LD) muscle; lane 5-8: treated group in LD muscle; lane 10: DL2000 marker; lane 11-14: control group in semitendinosus (ST) muscle; lane 15-18: treated group in ST muscle; and lane 9, 19: mixed sample.
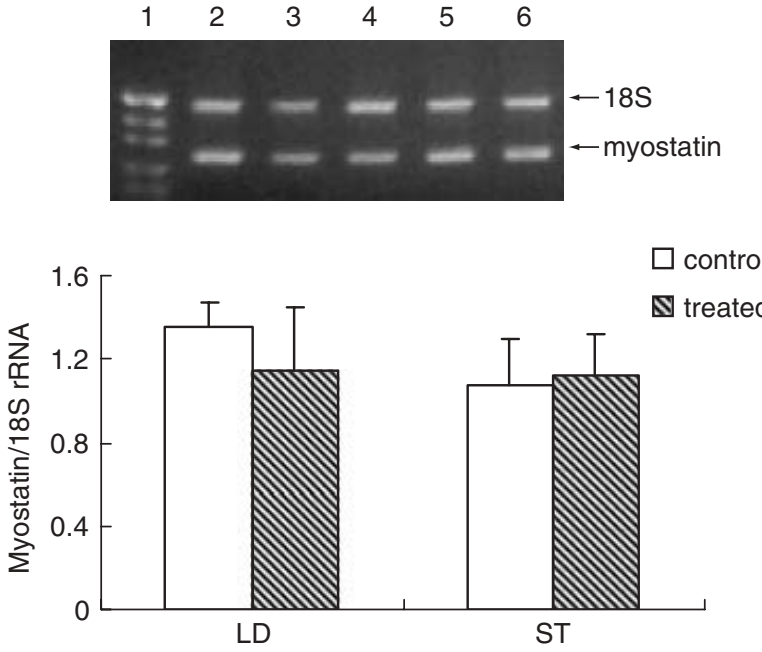

Figure 2 Effect of recombinant porcine growth hormone (rpGH) administration on myostatin mRNA in longissimus dorsi (LD) and semitendinosus (ST) muscles. Upper panel: representative electrophoresis photo. Lane 1: DNA marker PUC19; lane 2: control group in LD muscle; lane 3: treated group in LD muscle; lane 4: control group in ST muscle; lane 5: treated group in ST muscle; and lane 6: mixed sample. Lower panel: results of statistical analysis. No significant rpGH treatment effect, muscle effect or $\mathrm{rpGH}$ treatment $\times$ muscle interaction for myostatin mRNA expression were observed.

\section{Discussion}

In the present study, the myofibre-type distribution was not affected by rpGH administration in both LD and ST muscle, as detected with molecular-typing technique developed recently and applied elsewhere (Tanabe et al., 1999; Zhao et al., 2004). This is in agreement with previous findings obtained by using histochemical staining (Solomon et al., 1988 and 1990; Beermann et al., 1990; Ono et al., 1995; Sorensen et al., 1996) and by directly measuring the mRNA and protein levels of MyHC isoforms (Czerwinski and Martin, 1994). However, there have been some controversial results
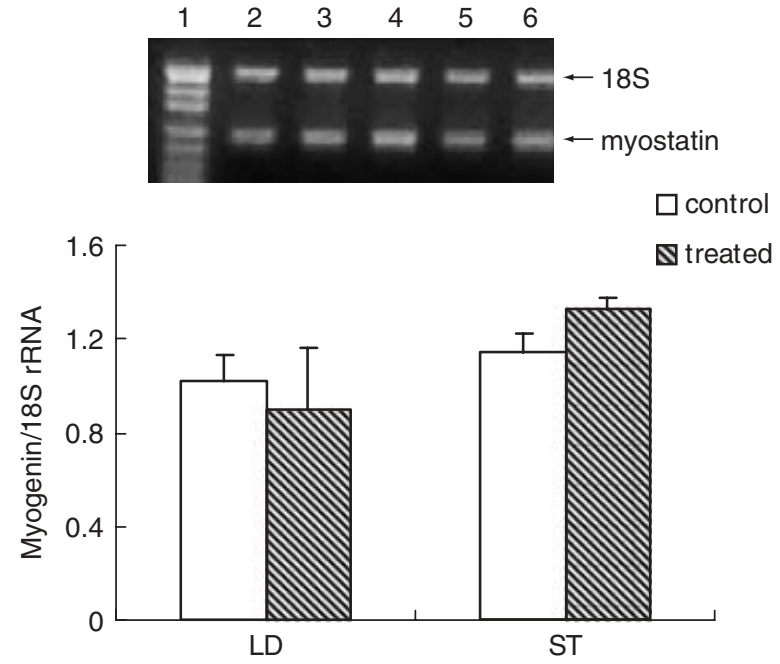

Figure 3 Effect of recombinant porcine growth hormone (rpGH) administration on myogenin mRNA in longissimus dorsi (LD) and semitendinosus (ST) muscles. Upper panel: representative electrophoresis photo. Lane 1: DNA marker PUC19; lane 2: control group in LD muscle; lane 3: treated group in LD muscle; lane 4: control group in ST muscle; lane 5: treated group in ST muscle; and lane 6: mixed sample. Lower panel: results of statistical analysis. No significant rpGH treatment effect, muscle effect or $\mathrm{rpGH}$ treatment $\times$ muscle interaction for myogenin mRNA expression was observed.

reported by Solomon et al. (1991) who found that at the body weight of 60 and $90 \mathrm{~kg}$, LD muscle of pigs injected with $100 \mu \mathrm{g} / \mathrm{kg}$ per day pGH from 30 to $60 \mathrm{~kg}$ possessed of more oxidative-glycolytic fibres and fewer glycolytic fibres. Later, it is reported that pGH-affected muscle fibre-type composition in a muscle type-specific pattern. ST muscle in pGH-treated pigs ( $100 \mu \mathrm{g} / \mathrm{kg}$ per day for 42 days) had more oxidative-glycolytic fibres and fewer glycolytic fibres at $30 \mathrm{~kg}$ of body weight, whereas this change was not observed in longissimus, semimembranosus and triceps muscle of the same pigs (Solomon et al., 1994). The reasons for such discrepancy concerning the effect of rpGH on 

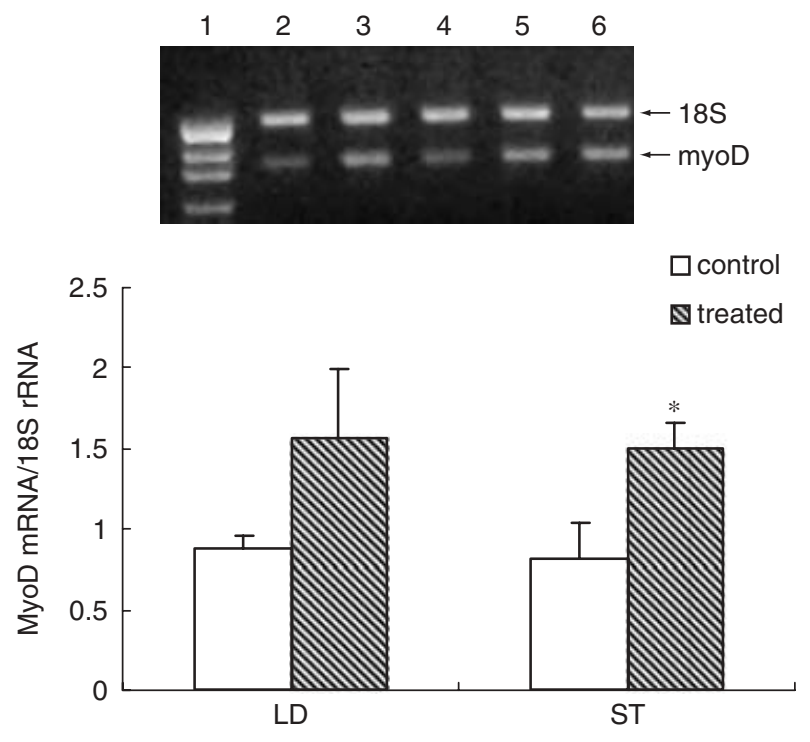

Figure 4 Effect of recombinant porcine growth hormone (rpGH) administration on myoD mRNA in longissimus dorsi (LD) and semitendinosus (ST) muscles. Upper panel: representative electrophoresis photo. Lane 1: DNA marker PUC19; lane 2: control group in LD muscle; lane 3 : treated group in LD muscle; lane 4: control group in ST muscle; lane 5: treated group in ST muscle; and lane 6: mixed sample. Lower panel: results of statistical analysis. No significant muscle effect or $\mathrm{rpGH}$ treatment $\times$ muscle interaction was seen for myoD mRNA expression. $A$ significant rpGH treatment effect $(P<0.05)$ was observed irrespective of muscle types. *Indicates significant difference between control and treated group when the differences were compared in LD and ST muscle, respectively $(P<0.05)$.
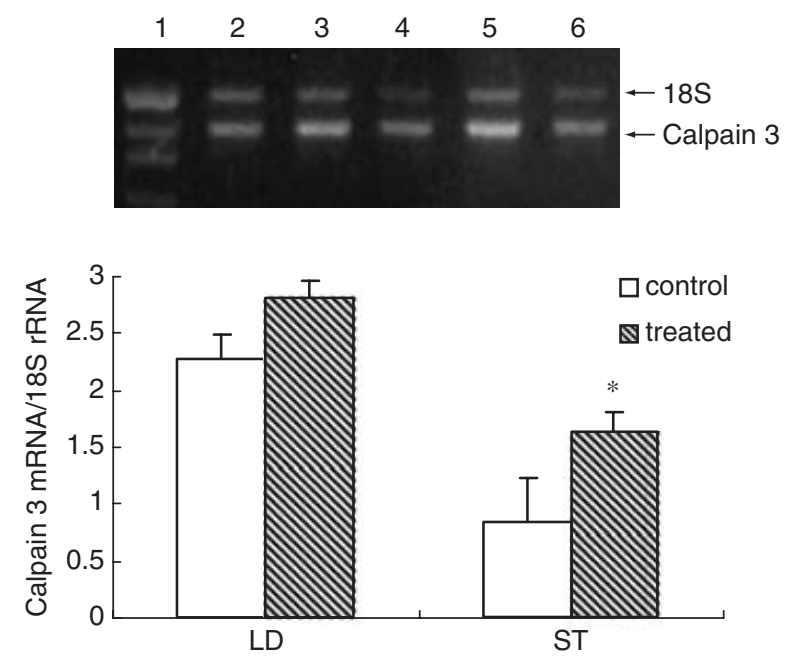

Figure 5 Effect of recombinant porcine growth hormone (rpGH) administration on calpain 3 mRNA in longissimus dorsi (LD) and semitendinosus (ST) muscles. Upper panel: representative electrophoresis photo. Lane 1: DNA marker PUC19; lane 2: control group in LD muscle; lane 3: treated group in LD muscle; lane 4: control group in ST muscle; lane 5: treated group in ST muscle; and lane 6: mixed sample. Lower panel: results of statistical analysis. No significant rpGH treatment $X$ muscle interaction was seen for calpain 3 mRNA expression. Significant muscle effect $(P<0.001)$ and rpGH treatment effect $(P<0.05)$ were observed. * indicates significant difference between control and treated group when the differences were compared in LD and ST muscle, respectively $(P<0.05)$.
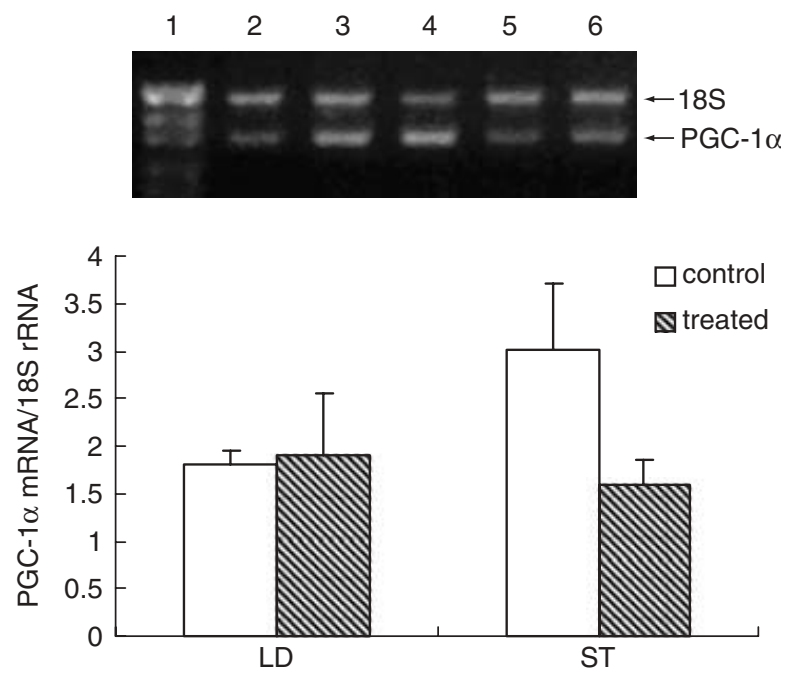

Figure 6 Effect of recombinant porcine growth hormone (rpGH) administration on PGC-1 $\alpha$ mRNA in longissimus dorsi (LD) and semitendinosus (ST) muscles. Upper panel: representative electrophoresis photo. Lane 1: DNA marker PUC19; lane 2: control group in LD muscle; lane 3: treated group in LD muscle; lane 4: control group in ST muscle; lane 5: treated group in ST muscle; and lane 6: mixed sample. Lower panel: results of statistical analysis. No significant rpGH treatment effect, muscle effect or rpGH treatment $\times$ muscle interaction for PGC- $1 \alpha$ mRNA expression were observed.

myofibre types are complex, which involve the age or the body weight when the animals started to receive the $\mathrm{rpGH}$ treatment, the length of the treatment, the doses, the routes of administration, the nutritional and physiological status (including genders) of the animals, as well as the muscle types and sensitivity and specificity of the methods used for myofibre typing.

Compared with the inconsistent effect of rpGH on myofibre types, the effect of rpGH on myofibre hypertrophy was observed in nearly all the published studies. Our previous finding of increased expression of GHR and IGF-1 mRNA in ST muscle upon GH administration would explain partly the mechanism of rpGH on myofibre hypertrophy (Zhao et al., 2003). However, the responses of candidate downstream genes, such as myostatin, myogenin, myoD, etc. following the activation of GHR and IGF-1, have not been clarified.

Myostatin knockout mice deposit two- to three-fold greater muscle mass than their wild-type littermates due to increase in both muscle fibre number (hyperplasia) and the fibre cross-sectional area (hypotrophy) (McPherron et al., 1997) during embryonic and early postnatal development (Wehling et al., 2000; Whittemore et al., 2003). A disruption of myostatin function by transgenic expression of its propetide (the $5^{\prime}$ region, 866 nucleotides) was reported to result in significant muscle growth (Yang et al., 2001). Nevertheless, the expression of myostatin mRNA did not seem to be influenced by rpGH administration in growing pigs (Ji et al., 1998), which is supported by our result that shows no significant difference in myostatin mRNA abundance between control and rpGH-treated pigs. These results 
hint that myostatin may not be involved in the pathway that mediates the effect of rpGH on muscle growth in pigs.

Myogenin and myoD both belong to the MRF family, but with different functions. MyoD is required for commitment of myoblasts during early myogenic process, whereas myogenin plays a pivotal role in the terminal differentiation of myofibres. Myogenin knockout mice can survive foetal development but die immediately after birth with a severe reduction of all skeletal muscles (Hasty et al., 1993). During myogenesis, the stimulation of differentiation by IGF-I is (at least in part) a result of substantially increased levels of the mRNA for myogenin (Florini et al., 1996). However, no information is available whether the expression of myoD and myogenin is influenced in rpGH-treated pigs. Our finding is that myogenin expression was unaffected while myoD mRNA expression was up-regulated especially in the ST muscle after rpGH administration. This may indicate that myogenin plays a specific role in early myogenesis or is not involved in the action of rpGH in pigs. Hughes et al. (1993 and 1997) reported a dramatic increase in myoD expression in the soleus muscle of rats after thyroid hormone treatment. Hence, myoD is not only responsible for myoblast commitment during embryonic myogenesis, but also participates in the satellite cell recruitment during fast growth induced by rpGH in postnatal life of pigs.

The muscle type-specific expression of myoD and myogenin has been addressed previously in some publications. Hughes et al. (1993) demonstrated that myoD selectively accumulative in the white muscle while myogenin is selectively accumulative in the red muscle in adult rats. But in cattle, Muroya et al. (2002) reported no significant difference in myogenin mRNA abundance among slow and fast muscles. Te Pas et al. (2000) noted that myogenin and myoD expression in different muscles were inconsistent in selection for leanness and selection for porcine growth rate. In our study, these two genes did not show selective expression patterns between the two types of muscle, which partly agrees with Te Pas et al. (2000) concerning the fast-growing pigs.

Calpain 3, as a skeletal muscle-specific protease, participates in the regulation of myogenesis in cultured $\mathrm{C}_{2} \mathrm{C} 12$ cell lines via its action on certain proteins belonging to the myogenic regulator factor (Dargelos et al., 2002). Mutations in the calpain 3 have been shown to be responsible for limb-girdle muscular dystrophy type 2A (Sorimachi et al., 1995). Jones et al. (1999) demonstrated that calpain 3 was present in all fibres of pigs but at a significantly lower level in slow type I compared with fast type IIA/IIB fibres, as observed in the present study. In the stopped growth caused by feeding a protein-free diet, van den HemelGrooten et al. (1997) demonstrated that the calpain 3 mRNA expression in LD muscle of pigs was significantly decreased. In the present study, calpain 3 expression increased upon rpGH administration. Moreover, the upregulation of calpain 3 expression was more remarkable in ST than in LD, demonstrating the muscle type-specific responses of this gene to rpGH treatment. However, Ji et al. (1998b) stated that calpain 3 showed no response to $3 \mathrm{mg} /$ day pGH injection in the longssimus muscle of barrow with the initial body weight of 64.2 to $67.4 \mathrm{~kg}$. This difference may be due to the methods used to detect the calpain 3 mRNA expression; the RT-PCR used in the present study is more sensitive than the ribonuclease protection assay used in Ji's study.

To our knowledge, this is the first report describing the effect of exogenous $\mathrm{GH}$ on the expression of PGC- $1 \alpha$ in domestic animals. Lin et al. (2002) demonstrated that PGC$1 \alpha$ was expressed preferentially in muscle enriched in type I fibres and drove the formation of the oxidative muscle fibre type (slow twitch) in transgenic mice. After prolonged lowintensity physical exercises, PGC- $1 \alpha$ expression was increased both in rats (Goto et al., 2000; Baar et al., 2002; Terada and Tabata, 2004; Taylor et al., 2005) and in humans (Russell et al., 2003), accompanied with the increased percentage of oxidative fibres. We found in our previous study that PGC-1 $\alpha$ mRNA abundance was significantly higher in LD muscle of Erhualian pigs (a Chinese indigenous breed) which possess more oxidative fibres (MyHC 1 and MyHC 2a) compared with Large White pigs (Zhao et al., 2004). In this context, the tendency of down-regulated PGC $-1 \alpha$ expression in ST muscle of treated pigs would indicate more anaerobic metabolisms although no significant alterations were detected for myofibre types. The small proportion of slow myofibre in LD muscle may be attributed to the irresponsiveness of PGC- $1 \alpha$ mRNA expression to $\mathrm{rpGH}$ treatment, as observed in the present experiment.

In conclusion, myoD, calpain 3 and probably PGC $-1 \alpha$ may be involved in the pathway that mediates the action of rpGH skeletal muscle growth. rpGH up-regulates mRNA expression of myoD and calpain 3 in a muscle type-specific manner, being more remarkable in oxidative fibre-enriched muscles.

\section{Acknowledgements}

This work was supported by National Basic Research Program of China (2004CB117505) and National Natural Science Foundation of China (project no. 39830290).

\section{References}

Baar K, Wende AR, Jones TE, Marison M, Nolte LA, Chen M, Kelly DP and Holloszy JO 2002. Adaptations of skeletal muscle to exercise: rapid increase in the transcriptional coactivator PGC-1. FASEB Journal 16, 1879-1886.

Beermann DH, Fishell VK, Roneker K, Boyd RD, Armbruster G and Souza L 1990. Dose-response relationships between porcine somatotropin muscle composition muscle fiber characteristics and pork quality. Journal of Animal Science 68, 2690-2697.

Brameld JM, Atkinson JL, Saunders JC, Pell JM, Buttery PJ and Gilmour RS 1996. Effects of growth hormone administration and dietary protein intake on insulin-like growth factor I and growth hormone receptor mRNA expression in porcine liver skeletal muscle and adipose tissue. Journal Animal Science 74, 1832-1841.

Campbell RG, Steele NC, Caperna TJ, McMurtry JP, Solomon MB and Mitchell $A D$ 1989. Effects of exogenous porcine growth hormone administration 
Muscle expression of myoD and calpain 3 responding to $r p G H$

between 30 and 60 kilograms on the subsequent and overall performance of pigs grown to 90 kilograms. Journal Animal Science 67, 1265-1271.

Chang KC, Da Costa N, Blackley R, Southwood O, Evans G, Plastow G, Wood JD and Richardson RI 2003. Relationships of myosin heavy chain fibers types to meat quality traits in traditional and modern pigs. Meat Science 64, 93-103.

Chomczynski P and Sacchi N 1987. Singlestep method of RNA isolation by acid guanidinium thiocyanate-phenol-chloroform extraction. Analytical Biochemistry $162,156-159$

Czerwinski SM and Martin JM 1994. Effect of somatotropin on myosin expression in pigs. Journal of Animal Science 72, 1204-1208.

Dargelos E, Moyen C, Dedieu S, Veschambre P, Poussard S, Vuillier-Devillers K, Brustis JJ and Cottin P 2002. Development of an inducible system to assess p94 (CAPN3) function in cultured muscle cells. Journal of Biotechnology 96, 271-279.

Eggert JM, Depreux FS, Schinckel AP, Grant AL and Gerrand DE 2002. Myosin heavy chain isoforms account for variation in pork quality. Meat Science 61 117-126.

Florini JR, Ewton DZ and Coolican SA 1996. Growth hormone and the insulinlike growth factor system in myogenesis. Endocrine Review 17, 481-517.

Goto M, Terada S, Kato M, Katoh M, Yokozeki T, Tabata I and Shimokawa T 2000. cDNA cloning and mRNA analysis of PGC-1 in epitrochlearis muscle in swimming-exercised rats. Biochemical and Biophysical Research Communications 274, 350-354.

Hamalainen N and Pette D 1993. The histochemical profiles of fast fiber types IIB, IID and IIA in skeletal muscles of mouse, rat and rabbit. Journal of Histochemistry and Cytochemistry 41, 733-743.

Hasty P, Bradley A, Morris JH, Edmondson DG, Venuti JM, Olson EN and Klein WH 1993. Muscle deficiency and neonatal death in mice with a targeted mutation in the myogenin gene. Nature 364, 501-506.

Hughes SM, Taylor JM, Tapscott SJ, Gurley CM, Carter WJ and Peterson CA 1993. Selective accumulation of MyoD and myogenin mRNAs in fast and slow adult skeletal muscle is controlled by innervation and hormones. Development 118, 1137-1147

Hughes SM, Koishi K, Rudnicki M and Maggs AM 1997. MyoD protein is differentially accumulated in fast and slow skeletal muscle fibres and required for normal fibre type balance in rodents. Mechanisms of Development 61, 151-163.

Ji S, Losinski RL, Cornelius SG, Frank GR, Willis GM, Gerrard DE, Depreux FF and Spurlock ME 1998a. Myostatin expression in porcine tissues: tissue specificity and developmental and postnatal regulation. The American Journal of Physiology 275, R1265-R1273.

Ji SQ, Frank GR, Cornelius SG, Willis GM and Spurlock ME 1998b. Porcine somatotropin improves growth in finishing pigs without altering calpain 3 (p94) or alpha-actin mRNA abundance and has a differential effect on calpastatin transcription products. Journal of Animal Science 76, 1389-1395. Jones SW, Parr T, Sensky PL, Scothern GP, Bardsley RG and Buttery PJ 1999. Fibre type-specific expression of p94 a skeletal muscle-specific calpain. Journal of Muscle Research and Cell Motility 20, 417-424.

Klindt J, Yen JT, Buonomo FC, Roberts AJ and Wise T 1998. Growth body composition and endocrine responses to chronic administration of insulin-like growth factor I and(or) porcine growth hormone in pigs. Journal of Animal Science 76, 2368-2381.

Klont RE, Brocks L and Eikelenboom G 1998. Muscle fiber type and meat quality. Meat Science 49 (suppl. 1), 219-229.

Knutti D and Kralli A 2001. PGC-1 a versatile coactivator. Trends in Endocrinology and Metabolism 12, 360-365.

Lee SJ and McPherron AC 1999. Myostatin and the control of skeletal muscle mass. Current Opinion in Genetics and Development 9, 604-607.

$\mathrm{Li} \mathrm{L}$ and Olson EN 1992. Regulation of muscle cell growth and differentiation by the MyoD family of helix-loop-helix proteins. Advances in Cancer Research 58, 95-119.

Lin J, Wu H, Tarr PT, Zhang CY, Wu Z, Boss O, Michael LF, Puigserver P, Isotani

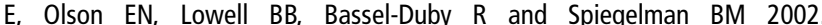
Transcriptional co-activator PGC-1 alpha drives the formation of slow-twitch muscle fibres. Nature 418, 797-801.

Louveau I and Bonneau M 1996. Effect of a growth hormone infusion on plasma insulin-like growth factor-I in Meishan and Large White pigs. Reproduction Nutrition Development 36, 301-310.
McPherron AC, Lawler AM and Lee SJ 1997. Regulation of skeletal muscle mass in mice by a new TGF-beta superfamily member. Nature 387, 83-90.

Molkentin JD and Olson EN 1996. Defining the regulatory networks for muscle development. Current Opinion in Genetics and Development 6, 445-453.

Muroya S, Nakajima I and Chikuni K 2002. Related expression of MyoD and Myf5 with myosin heavy chain isoform types in bovine adult skeletal muscles. Zoological Science 19, 755-761.

National Research Council 1998. Nutrient requirements of domestic animals: nutrient requirement of swine, 10th edition. National Academy Press, Washington, DC, USA

Olson EN 1990. MyoD family: a paradigm for development? Genes and Development 4, 1454-1461.

Ono Y, Solomon MB, Evock-Clover CM, Steele NC and Maruyama K 1995. Effects of porcine somatotropin administration on porcine muscles located within different regions of the body. Journal of Animal Science 73, 2282-2288. Russell AP, Feilchenfeldt J, Schreiber S, Praz M, Crettenand A, Gobelet C, Meier CA, Bell DR, Kralli A, Giacobino JP and Deriaz 0 2003. Endurance training in humans leads to fiber type-specific increases in levels of peroxisome proliferator-activated receptor-gamma coactivator-1 and peroxisome proliferator-activated receptor-alpha in skeletal muscle. Diabetes 52, 2874-2881.

Sharma M, Langley B, Bass J and Kambadur R 2001. Myostatin in muscle growth and repair. Exercise and Sport Sciences Reviews 29, 155-158.

Solomon MB, Campbell RG, Steele NC, Caperna TJ and McMurtry JP 1988. Effect of feed intake and exogenous porcine somatotropin on longissimus muscle fiber characteristics of pigs weighing 55 kilograms live weight. Journal of Animal Science 66, 3279-3284.

Solomon MB, Campbell RG and Steele NC 1990. Effect of sex and exogenous porcine somatotropin on longissimus muscle fiber characteristics of growing pigs. Journal of Animal Science 68, 1176-1181.

Solomon MB, Campbell RG, Steele NC and Caperna TJ 1991. Effects of exogenous porcine somatotropin administration between 30 and 60 kilograms on longissimus muscle fiber morphology and meat tenderness of pigs grown to 90 kilograms. Journal of Animal Science 69, 641-645.

Solomon MB, Caperna TJ, Mroz RJ and Steele NC 1994. Influence of dietary protein and recombinant porcine somatotropin administration in young pigs: III. Muscle fiber morphology and shear force. Journal of Animal Science 72, 615-621.

Sorensen MT, Oksbjerg N, Agergaard N and Petersen JS 1996. Tissue deposition rates in relation to muscle fibre and fat cell characteristics in lean female pigs (Sus scrofa) following treatment with porcine growth hormone (pGH). Comparative Biochemistry and Physiology - Part A: Physiology 113, 91-96.

Sorimachi H, Imajoh-Ohmi S, Emori $Y$, Kawasaki H, Ohno S, Minami $Y$ and Suzuki K 1989. Molecular cloning of a novel mammalian calcium-dependent protease distinct from both $\mathrm{m}$ - and mu-types. Specific expression of the mRNA in skeletal muscle. Journal of Biological Chemistry 264, 20106-20111.

Sorimachi H, Ohmi S, Emori Y, Kawasaki H, Saido TC, Ohno S, Minami $Y$ and Suzuki K 1990. A novel member of the calcium-dependent cysteine protease family. Biological Chemistry Hoppe Seyler 371 (suppl.), 171-176.

Sorimachi H, Kinbara K, Kimura S, Takahashi M, Ishiura S, Sasagawa N Sorimachi N, Shimada H, Tagawa K and Maruyama K 1995. Muscle-specific calpain p94 responsible for limb girdle muscular dystrophy type $2 \mathrm{~A}$ associates with connectin through IS2 a p94-specific sequence. Journal of Biological Chemistry 270, 31158-31162.

Statistical Pakages for the Social Sciences 2001. SPSS for Windows. SPSS, Chicago, IL.

Tanabe R, Muroya S and Chikuni K 1999. Expression of myosin heavy chain isoforms in porcine muscles determined by multiplex PCR. Journal of Food Science 64, 222-225.

Taylor EB, Lamb JD, Hurst RW, Chesser DG, Ellingson WJ, Greenwood LJ, Porter BB, Herway ST and Winder WW 2005. Endurance training increases skeletal muscle LKB1 and PGC-1alpha protein abundance: effects of time and intensity. American Journal of Physiology - Endocrinology and Metabolism 289, E960-E968.

Te Pas MF, Verburg FJ, Gerritsen CL and de Greef KH 2000. Messenger ribonucleic acid expression of the MyoD gene family in muscle tissue at slaughter in relation to selection for porcine growth rate. Journal of Animal Science 78, 69-77. 
Terada S and Tabata I 2004. Effects of acute bouts of running and swimming exercise on PGC-1alpha protein expression in rat epitrochlearis and soleus muscle. American Journal of Physiology Endocrinology and Metabolism 286, E208-E216.

Van den Hemel-Grooten HN, te Pas MF, van den Bosch TJ, Garssen GJ, Schreurs VV and Verstegen MW 1997. mRNA levels of the calpain system in longissimus muscle of young pigs during prolonged feeding of a protein-free diet. Journal of Animal Science 75, 968-974.

Wehling M, Cai B and Tidball JG 2000. Modulation of myostatin expression during modified muscle use. FASEB Journal 14, 103-110.

Whittemore LA, Song K, Li X, Aghajanian J, Davies M, Girgenrath S, Hill JJ, Jalenak M, Kelley P, Knight A, Maylor R, O'Hara D, Pearson A, Quazi A, Ryerson S, Tan XY, Tomkinson KN, Veldman GM, Widom A, Wright JF, Wudyka S, Zhao L and Wolfman NM 2003. Inhibition of myostatin in adult mice increases skeletal muscle mass and strength. Biochemical and Biophysical Research Communications 300, 965-971.
Yang J and Zhao B 2006. Postnatal expression of myostatin propeptide cDNA maintained high muscle growth and normal adipose tissue mass in transgenic mice fed a high-fat diet. Molecular reproduction and development 73 , 462-469.

Yang J, Ratovitski T, Brady JP, Solomon MB, Wells KD and Wall RJ 2001. Expression of myostatin pro domain results in muscular transgenic mice. Molecular Reproduction and Development 60, 351-361.

Zhao RQ, Zhou J, Xu QF, Zhao ZH, Wei XH, Xia D and Chen WH 2003. Tissuespecific effect of recombinant porcine growth hormone on expression of growth-related genes in the pig. Journal of Animal and Feed Science 12, 595-605.

Zhao RQ, Yang XJ, Wei XH, Xia D and Chen J 2004. Expression of GHR and PGC-1 in association with changes of MyHC isoform types in longissimus muscle of Erhualian and Large White pigs (Sus scrofa) during postnatal growth. Animal Science 79, 203-211. 